\title{
Oocyte Quality Control: Causes, Mechanisms, and Consequences
}

\author{
NeIL HunTER ${ }^{1,2,3,4}$ \\ ${ }^{1}$ Howard Hughes Medical Institute, University of California, Davis, Davis, California 95616 \\ ${ }^{2}$ Department of Microbiology and Molecular Genetics, University of California, Davis, \\ Davis, California 95616 \\ ${ }^{3}$ Department of Molecular and Cellular Biology, University of California, Davis, Davis, California 95616 \\ ${ }^{4}$ Department of Cell Biology and Human Anatomy, University of California, Davis, \\ Davis, California 95616 \\ Correspondence: nhunter@ucdavis.edu
}

\begin{abstract}
Oocyte quality and number are key determinants of reproductive life span and success. These variables are shaped in part by the elimination of oocytes that experience problems during the early stages of meiosis. Meiotic prophase-I marks an extended period of genome vulnerability in which epigenetic reprogramming unleashes retroelements and hundreds of DNA doublestrand breaks (DSBs) are inflicted to initiate the programmed recombination required for accurate chromosome segregation at the first meiotic division. Expression of LINE-1 retroelements perturbs several aspects of meiotic prophase and is associated with oocyte death during the early stages of meiotic prophase I. Defects in chromosome synapsis and recombination also trigger oocyte loss, but typically at a later stage, as cells transition into quiescence and form primordial follicles. Interrelated pathways that signal defects in DSB repair and chromosome synapsis mediate this late oocyte attrition. Here, I review our current understanding of early and late oocyte attrition based on studies in mouse and describe how these processes appear to be both distinct and overlapping and how they help balance the quality and size of oocyte reserves to maximize fecundity.
\end{abstract}

The common fate of a mammalian oocyte is an early death, with $\sim 80 \%$ of human oocytes being lost before or shortly after birth (Fig. 1; Baker 1963; Kurilo 1981). The size and quality of the surviving pool of primordial follicles are important determinants of female fecundity and reproductive life span (Broekmans et al. 2007). Oogenesis begins during fetal development following the establishment of primordial germ cells in the undifferentiated gonads. The ensuing oogonia expand by mitosis such that very large numbers of primary oocytes enter meiosis, approximately six to seven million in humans. However, by birth, oocyte numbers have already crashed down to approximately one to two million and at the onset of puberty only approximately 200,000 to 300,000 remain (Fig. 1; Block 1953; Baker 1963; Forabosco et al. 1991). This finite ovarian reserve (Gleicher et al. 2011) comprises nongrowing primordial follicles arrested in the dictyate stage of meiosis, before the first meiotic division. Ovarian reserves are continually depleted through ongoing recruitment of primordial follicles to the growing follicle pool, and cyclical follicle-stimulating hormone (FSH)dependent activation of cohorts of antral follicles to reenter meiosis (McGee and Hsueh 2000). For both recruitment and activation phases, the default outcome is again cell death through an apoptotic process termed atresia (Kaipia and Hsueh 1997), with only the dominant ovulatory follicle(s) completing the meiosis I division. Thus, only approximately 350 oocytes will escape cell death and be ovulated during the human reproductive life span, corresponding to $<0.006 \%$ of the $6-7$ million potential eggs initially formed during fetal development. Follicle depletion is associated with reduced production of the hormones estrogen and inhibin by the ovary, disrupting the hypothalamic-pituitary-gonadal (HPG) hormonal axis and eventually leading to menopause (Honour 2018). Thus, follicle depletion serves as a timer for the major landmarks of female reproduction (Broekmans et al. 2007). Moreover, genetic and environmental factors that influence the size of initial ovarian reserves and rates of follicle recruitment can significantly alter reproductive life span (Gleicher et al. 2011; Tilly and Sinclair 2013; Aiken et al. 2015; Findlay et al. 2015; Grive and Freiman 2015; Laven 2015, 2016; Laven et al. 2016).

The causes, mechanisms, and roles of the massive oocyte culling that occurs during fetal and early postnatal life have been the subject of much study and debate (Tilly 2001; Hartshorne et al. 2009). However, cumulative evidence from studies in mouse indicates that much of the oocyte death during this period is the result of quality control processes that eliminate potentially defective cells and nurture the cells that will survive (Di Giacomo et al. 2005; Lei and Spradling 2013, 2016; Malki et al. 2014). Two major stages of oocyte loss can be inferred in mouse (Fig. 2). Early oocyte attrition (EOA) occurs between embryonic days E15.5 and E8.5 and causes the loss of $\sim 50 \%$ of all oocytes (Malki et al. 2014). Late oocyte attrition (LOA) follows in the early postnatal period as cells transition into quiescence to establish the pool of

(C) 2017 Hunter. This article is distributed under the terms of the Creative Commons Attribution-NonCommercial License, which permits reuse and redistribution, except for commercial purposes, provided that the original author and source are credited. 


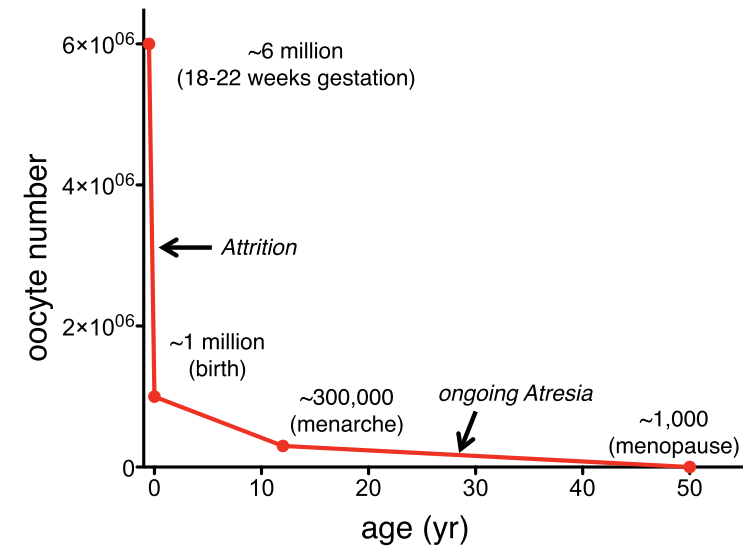

Figure 1. Oocyte decline in human fetal ovaries. Approximately $80 \%$ of the oocytes that enter meiosis are culled by birth and less than half of those remaining survive through puberty. Through ongoing atresia, following recruitment and hormonal activation, oocyte numbers continually decline until the hypothalamic-pituitary-gonadal (HPG) hormonal axis can no longer be supported and menopause ensues.

resting follicles (Di Giacomo et al. 2005; Klinger et al. 2015; Qiao et al. 2018). Not only are these two stages of oocyte death temporally distinct, but they also appear to have different underlying causes. In mouse, EOA is cor- related with the activation of LINE-1 transposons (Malki et al. 2014), whereas LOA appears to be a response to errors in meiotic prophase I (Fig. 2; Di Giacomo et al. 2005; Bolcun-Filas et al. 2014; Rinaldi et al. 2017a). However, oocyte attrition is also generally associated with developmental processes in the nascent ovary (Pepling and Spradling 1998; Lei and Spradling 2013, 2016). These processes begin with the formation of clonal cysts comprising approximately 30 primordial germ cells interconnected in a syncytium. Coincident with meiotic prophase I, cysts then break down and reorganize into nonclonal nests. Concurrently, interconnected cells are differentiating into oocytes targeted for survival and nurse-like cells that nurture the developing oocytes by donating organelles and cytoplasm (Lei and Spradling 2016). Analogous to the well-characterized nurse cells of the Drosophila ovary (Jenkins et al. 2013), this selfsacrifice of mouse nurse-like cells concludes in programmed cell death prior to follicle formation.

\section{DEREPRESSION OF LINE-1 ELEMENTS AND EARLY OOCYTE ATTRITION}

Long interspersed element 1, LINE-1 (L1), is the only autonomous retroelement that remains active in the human genome (Cordaux and Batzer 2009). It belongs to the non-

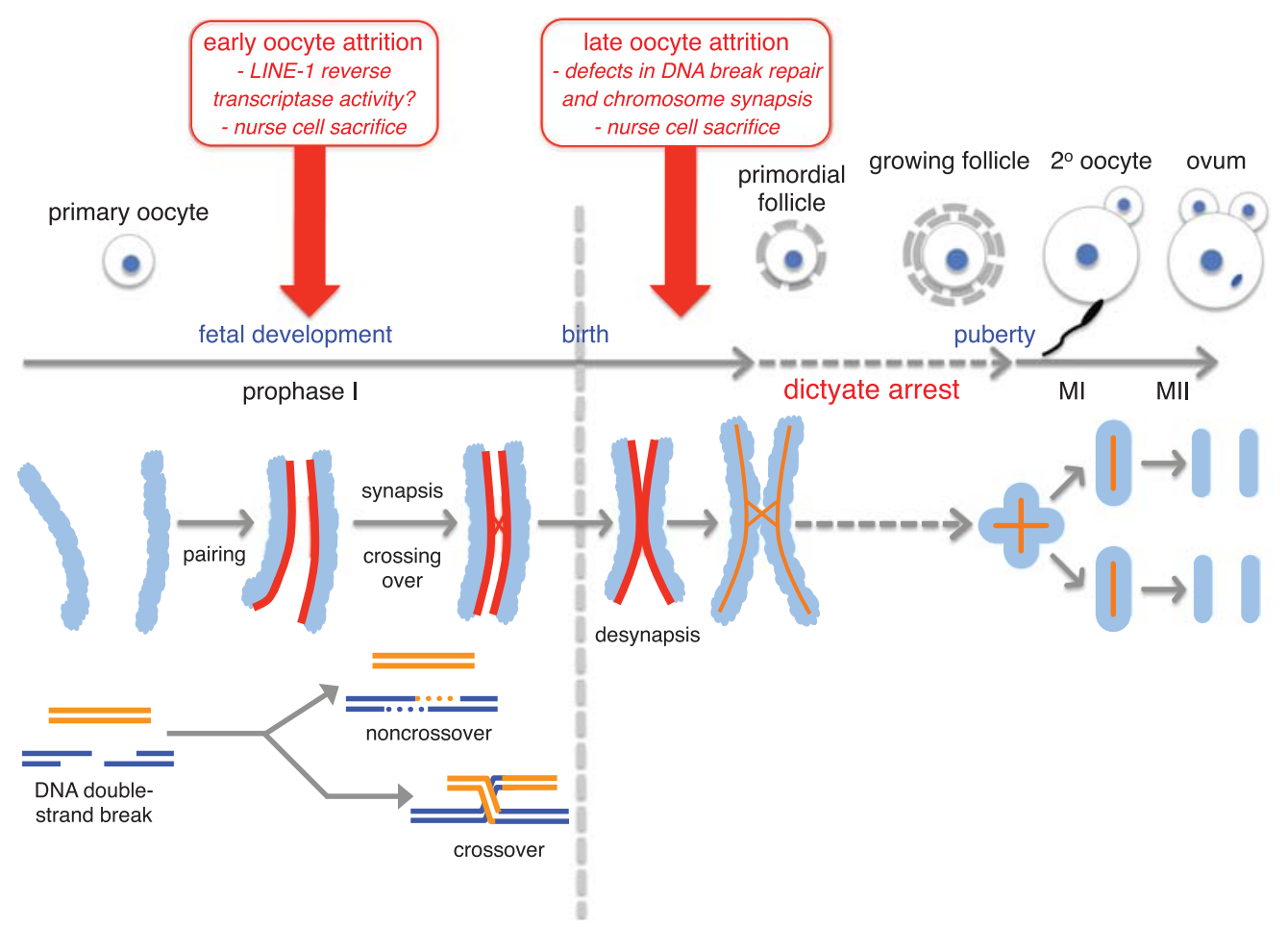

Figure 2. Time line of oocyte meiosis in mouse highlighting nuclear (top), chromosomal (middle), and recombination (bottom) landmarks. Pairing, synapsis, and crossing-over between homologous chromosomes are facilitated by programmed homologous recombination initiated by hundreds of DNA double-strand breaks. Early oocyte attrition (EOA) occurs during early meiotic prophase-I and is correlated with LINE-1 activity. Late oocyte attrition (LOA) occurs after homologs desynapse and oocytes begin to transition into dictyate arrest. LOA can be triggered by unrepaired DNA breaks and transcriptional silencing induced at sites where synapsis has failed. Meiosis only resumes in oocytes that have been recruited for growth and activated by follicle-stimulating hormone (FSH). Only the dominant ovulatory follicle will complete the meiosis-I division before arresting in metaphase II until fertilization. 
long terminal repeat retrotransposon class of transposable elements that also includes nonautonomous $A l u$ and SVA elements and makes up around one-third of the human genome. L1 alone accounts for $\sim 17 \%$ of the human genome-more than 500,000 copies-but less than 100 copies are thought to remain functional (Brouha et al. 2003). These full-length $\mathrm{L} 1$ elements are $\sim 6 \mathrm{~kb}$ in length and comprise a 5' UTR containing an RNA Pol II promoter, two open reading frames (ORFs), and a 3' UTR that terminates with a poly(A) tail and contains a polyadenylation signal (Babushok and Kazazian 2007). The ORFs encode activities required for transposition: ORF1 is a nucleic acid chaperone, and ORF2 has endonuclease and reverse transcriptase activities.

L1 transcripts are exported from the nucleus and translated. The ORF1 and ORF2 proteins bind with a strong cis bias to the mRNA that encoded them, assembling into ribonucleoprotein (RNP) complexes that reenter the nucleus to mediate transposition. In a process termed targetsite-primed reverse transcription, the ORF2 endonuclease nicks the target-site DNA at the consensus sequence (5'TTTT/AA-3'). The resulting 5'-TTTT-3'-OH strand anneals to the poly(A)-tail of the associated L1 mRNA to prime the ORF2 reverse transcriptase (Cost et al. 2002). Nicking of the second DNA strand of the target DNA is thought to provide a primer for second strand synthesis to complete L1 integration. Although the ORF1 and ORF2 proteins tend to bind to their cognate L1 mRNA, transactivation of abundant Alu and SVA nonautonomous retroelements and other cellular mRNAs can occur (Esnault et al. 2000; Dewannieux et al. 2003; Ostertag et al. 2003; Beck et al. 2011).

\section{Consequences of LINE-1 Activity}

The activities of L1 and other transposable elements have had profound effects on cellular function, genome stability, and evolution. Cis and trans activity of L1 is a major source of insertional mutagenesis, both somatic and germline, and is implicated in numerous diseases including cancer (Cordaux and Batzer 2009). Over the course of human evolution, insertion of more than 8000 human processed pseudogenes and more than a million nonautonomous retroelements are attributed to L1 activity (Zhang et al. 2003; Vinckenbosch et al. 2006).

ORF2 endonuclease activity can serve as a source of genome instability by generating DNA double-strand breaks (DSBs) uncoupled from successful transposition (Belgnaoui et al. 2006; Gasior et al. 2006). L1 insertion can also bypass the need for the ORF2 endonuclease by hijacking endogenous DSBs (Morrish et al. 2002). Although this endonuclease-independent insertion may facilitate DSB repair, it also has the potential to interfere with endogenous repair pathways as well as causing potentially deleterious insertions. Both endonucleasedependent and -independent insertion has been associated with local DNA rearrangements including deletions, duplications, inversions, and translocations (Belancio et al. 2008). L1 itself is a source of unstable microsatellite sequences and insertion generates additional poly(A) microsatellites de novo (Grandi and An 2013).

L1 insertion also influences transcription, both positively and negatively. An antisense promoter in the 5' UTR can drive transcription of flanking cellular genes and appears to be broadly used in tissue-specific gene regulation (Nigumann et al. 2002). Oppositely, as targets of heterochromatin formation, L1 elements can locally silence gene expression (Slotkin and Martienssen 2007). Intragenic L1 elements can impede transcription (Han et al. 2004) and serve as sense and antisense promoters (Faulkner et al. 2009), alternative splice junctions (Belancio et al. 2006, 2008), and termination sites (Lee et al. 2008). More generally, L1 expression is associated with cellular responses such as activation of the innate-immune response (Crow 2010; Goodier et al. 2015) and the DNA-damage response (Belgnaoui et al. 2006) and their downstream effects such as cell cycle arrest, senescence, and apoptosis (Belgnaoui et al. 2006; Gasior et al. 2006; Wallace et al. 2008).

\section{Multiple Layers of LINE-1 Repression}

Given the potentially catastrophic effects of L1 activity, cells have evolved defense mechanisms to interfere with each step of its life cycle (Goodier 2016; Pizarro and Cristofari 2016; Liu et al. 2018). At the level of initiation, the L1 promoter is suppressed by CpG DNA methylation (Hata and Sakaki 1997; Bourc'his and Bestor 2004) and the 5' UTR has come under the control of host transcription factors (Tchenio et al. 2000; Yang et al. 2003; Athanikar et al. 2004). Consistently, L1 transcriptional repression also involves a variety of histone modifications (Castañeda et al. 2011) including de novo H3 Lys9 trimethylation by the "human silencing hub" complex (Liu et al. 2018). Involvement of the SMC complex condensin in restricting retotransposons, including L1, also indicates a repressive role for higher-order chromatin structure (Schuster et al. 2013; Ward et al. 2017). piwi-interacting small RNA (piRNA) biogenesis is a particularly important mechanism for silencing transposable elements, including L1, in the germline and is also required for their de novo remethylation (Aravin et al. 2008; KuramochiMiyagawa et al. 2008; Castañeda et al. 2011). Posttranscriptionally, RNA interference, degradation, premature polyadenylation, and editing can attenuate LINE-1 activity (Perepelitsa-Belancio and Deininger 2003; Yang and Kazazian 2006; Schumann 2007; Zhang et al. 2014; Hamdorf et al. 2015; Orecchini et al. 2018).

At the posttranslational level, the ubiquitin-proteasome system targets the L1ORF1 protein via TEX19.1 and the E3-ligase UBR2 (MacLennan et al. 2017). A DNA exonuclease, TREX1, is thought to destroy the reverse transcribed cDNA strand of L1 (Stetson et al. 2008). TREX1 also has an exonuclease-independent function that reduces L1 ORF1 protein levels (Li et al. 2017). SAMHD1, a dNTP triphosphohydrolase, is inferred to impede nuclear import of L1 RNPs by enhancing their sequestration in stress granules (Hu et al. 2015), cytoplasmic structures that accumulate untranslated mRNAs when cells 
are stressed (Sheinberger and Shav-Tal 2017). TREX1, SAMHD1, and several other repressors of L1 activity are downstream components of the interferon (IFN) response pathway (Goodier et al. 2015). Involvement of these innate restriction factors implies that L1 induces an innate immune response, perhaps through detection of L1 RNA: DNA hybrids or L1 encoded proteins (Crow 2010; Rigby et al. 2014). Host DNA repair factors have also been implicated in suppression of late steps of L1 integration (Pizarro and Cristofari 2016; Servant et al. 2017; Liu et al. 2018). Notably, the ERCC1-XPF endonuclease has been proposed to remove the branched intermediates of L1ORF2 reverse transcription (Gasior et al. 2008).

\section{Epigenetic Reprogramming Is Coincident with Meiosis in Females}

As primordial germ cells migrate, DNA methylation $(5 \mathrm{mC})$ is removed throughout the genome as a primary step in the global epigenetic reprogramming required for gametogenesis and ensuing embryogenesis (Seisenberger et al. 2012; Messerschmidt et al. 2014). In oocytes, the demethylated state is sustained throughout fetal development and only restored after birth. As such, meiotic prophase-I in females occurs in the context of a globally hypomethylated genome. In contrast, males restore DNA methylation at the prospermatogonial stage during the perinatal period, long before meiosis initiates. Hypomethylation causes a burst of L1 expression. In mouse, although LINE-1 RNA is detectable in primordial germ cells, it may not be translated until oocytes are in meiotic prophase (Trelogan and Martin 1995; Seisenberger et al. 2012). Also, intriguingly, although L1 expression peaks during meiosis, retrotransposition appears to occur mainly during embryogenesis and may be mediated by L1 RNA that was transmitted via the gametes (Kano et al. 2009).

Along with DNA demethylation, the global changes in chromatin organization and transcriptional reprogramming that characterize meiotic prophase may render primary oocytes uniquely disposed to high levels of L1 expression. Early meiotic prophase is characterized by interactions between pairs of homologous chromosomes (homologs) and their physical connection by crossovers (Fig. 2; Hunter 2015). Following S phase, meiotic chromosomes organize into stereotypic structures comprising linear arrays of chromatin loops, the bases of which organize into cores or axes that defines the interfaces for homologous interactions (Zickler and Kleckner 1999, 2015). Importantly, this global, semicompact loop-axis organization supersedes the higher-order structures (chromatin loops, topologically associating domains, and epigenetic compartments) that mediate transcriptional regulation in somatic cells (Dekker and Mirny 2016; Hansen et al. 2018). Other chromatin changes such as nucleosome composition and histone modifications, including those associated with meiotic recombination, could also enhance L1 activity during meiosis (Saitou et al. 2012; Ng et al. 2013; Székvölgyi et al. 2015; Izquierdo-Bouldstridge et al. 2017).

\section{LINE-1 Derepression during Oogenesis Is Associated with Multiple Defects}

The major events of meiotic prophase- homolog pairing, synapsis, and crossing-over-are mediated by programmed homologous recombination initiated by DNA breakage (Fig. 2; Lam and Keeney 2014; Hunter 2015). During the leptotene stage, SPO11 protein catalyzes DSB formation, inflicting on the order of 200-300 DNA DSBs per nucleus in mouse and human (Cole et al. 2012; Gruhn et al. 2013). Ensuing interhomolog DNA pairing and strand exchange bring chromosomes into close juxtaposition, enabling formation of synaptonemal complexes (SCs), densely packed transverse filaments that connect homologous chromosomes along their lengths (Zickler and Kleckner 1999). SCs form during zygotene and crossovers form in the context of fully synapsed SCs during the pachytene stage. Crossover formation is tightly regulated such that each pair of chromosomes becomes connected by at least one exchange, as required for accurate segregation at the meiosis-I division. Homologs then desynapse and cells enter diplotene. At this stage, oocytes then transition onto the protracted dictyate stage and become surrounded by a single layer of supporting granulosa cells to establish the reserve of primordial follicles (Fig. 2). After puberty, meiosis resumes in FSH-activated follicles and meiosis-I ensues in the dominant ovulatory cell.

L1ORF1 protein is readily detected in the nuclei of mouse fetal oocytes during early prophase stages, and striking cell-to-cell variation is observed implying stochastic variation in L1 activity (Malki et al. 2014). However, cytoplasmic transfer from syncytial nurse-like cells could help lower L1 activity in differentiating oocytes and contribute to the observed variation in L1ORF1 levels (Lei and Spradling 2016). Several lines of evidence point to a causal role for L1 in EOA and imply that oocytes with excessive L1 expression are targeted for killing (Malki et al. 2014): (i) EOA is enhanced when the piRNA pathway is defective; (ii) ORF1 protein levels correlate with oocyte survival; (iii) expression of an L1 transgene enhances EOA; and (iv) the nucleoside analog azidothymidine AZT, which presumptively inhibits of L1ORF2 reverse transcriptase activity (Jones et al. 2008; Dai et al. 2011), prevents EOA at normal times (between embryonic day E13.5 and E18.5), suggesting that a reverse transcriptase intermediate triggers EOA during this period (Fig. 3). However, oocyte death is not permanently rescued by AZT, and by 2 days postpartum (dpp), numbers drop to levels seen in untreated controls, suggesting that reverse transcriptase-independent activities of L1 can contribute to LOA (see below).

L1 expression during meiosis is associated with the formation of SPO11-independent DSBs (Soper et al. 2008; Carofiglio et al. 2013) and provokes a variety of prophase errors including persistent DNA damage, synapsis defects, reduced crossing-over, and elevated chromosome missegregation (Fig. 3; Malki et al. 2014). The DNA repair and synapsis defects are not relieved by AZT treatment consistent with the possibility that they result from 


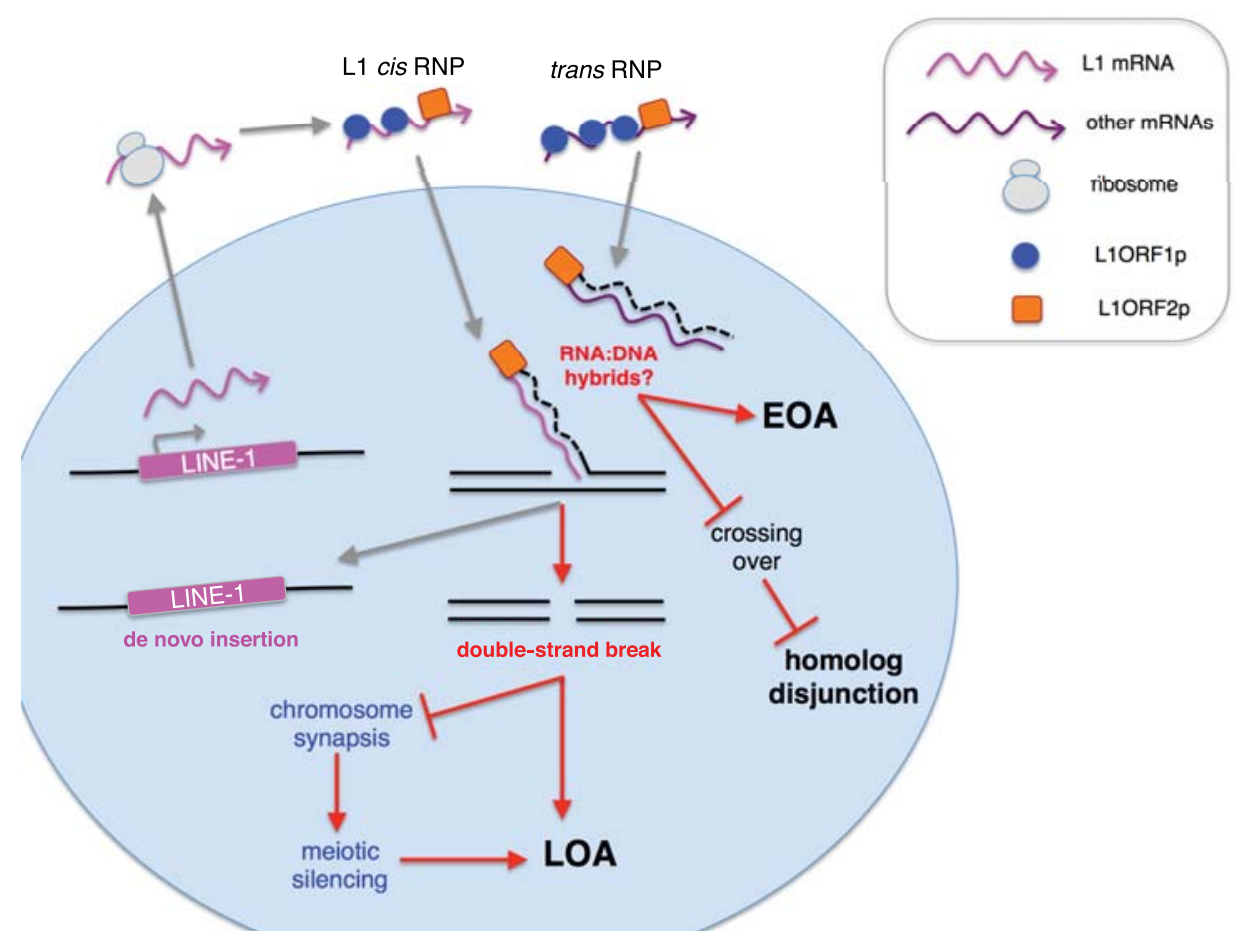

Figure 3. LINE-1 activities during early prophase-I perturb meiosis and may trigger early oocyte attrition (EOA) and late oocyte attrition (LOA). DNA demethylation leads to derepression of full-length LINE-1 (L1) elements during oocyte meiosis. L1ORF1 and ORF2 proteins are translated and assemble into RNP complexes, showing a string cis bias for the encoding L1 mRNA, but transactivation of non-L1 mRNAs can also occur. Target site nicking by the L1ORF2 enodonuclease primes the L1ORF2 reverse transcriptase to synthesize an RNA:DNA hybrid intermediate. Nicking of the other strand and second-strand synthesis leads to L1 integration. RNA:DNA hybrids trigger EOA and interfere with crossing-over, elevating the risk of chromosome missegregation. Aberrant L1 activity may also lead to double-strand break formation and defective synapsis leading to LOA.

DNA damage inflicted by the L1ORF2 endonuclease. Intriguingly, AZT does suppress the crossover deficit associated with excessive L1 expression. In fact, wildtype oocytes make $\sim 10 \%$ more crossovers when treated with AZT, indicating that L1ORF2 reverse transcriptase activity somehow interferes with the process of meiotic crossing-over (Malki et al. 2014).

Notably, meiosis in human females shows a high degree of heterogeneity relative to males, with frequent synaptic errors and highly variable crossover numbers (Hassold and Hunt 2001; Lenzi et al. 2005; Tease et al. 2006; Hassold et al. 2007; Hunt and Hassold 2008; Gruhn et al. 2013). Moreover, crossover patterning in females is suboptimal, producing outcomes that are at risk for chromosome missegregation, such as nonexchange chromosomes and chromosomes with a single crossover located close to a centromere or telomere (Cheng et al. 2009; Nagaoka et al. 2012; Herbert et al. 2015). A key factor underlying this defect is inefficient maturation of crossovers, which is inferred to occur with only $\sim 75 \%$ efficiency in females (Wang et al. 2017). The association between L1 activity, increased synaptic errors, and decreased crossover formation in mouse (Malki et al. 2014) raises the possibility that L1 and/or other transposable elements contribute to the inefficient crossover maturation and elevated aneuploidy seen in human females.

In sum, analysis in mouse suggests that L1 activity induces EOA via a reverse transcriptase-dependent inter- mediate, although direct evidence for this inference remains an important goal (Fig. 3; Malki et al. 2014). One possibility is that L1-catalyzed RNA:DNA hybrids trigger an innate immune response. Alternatively, L1-mediated RNA:DNA hybrids may interfere with protein translation as observed in human platelets (Schwertz et al. 2018). Also, whether EOA occurs via canonical apoptotic pathways and its relationship to nurse cell sacrifice remain unclear.

By inflicting additional DNA damage on top of the hundreds of programmed DSBs, L1 activity could push damage signaling above a threshold not normally reached during early prophase and sufficient to induce cell death. However, the AZT sensitivity of EOA suggests that L1-induced DNA damage is not the cause of early oocyte death. In fact, the early prophase period of oocyte meiosis appears to be relatively insensitive to DNA damageinduced apoptosis. For example, recombination mutants that fail to repair DSBs, even those with elevated DSB levels such as $\mathrm{Atm}^{-/}$, induce oocyte culling at the prefollicle stage (Di Giacomo et al. 2005), not during early prophase as seen for L1-associated EOA. Also, zygotene/ pachytene-stage oocytes are relatively resistant to irradiation-induced apoptosis compared to those in diplotene (Hanoux et al. 2007; Kim and Suh 2014; Hunter N, unpubl. data). It makes sense that oocytes should suppress DNA damage-induced apoptosis pathways during these stages while hundreds of programmed meiotic 
DSBs are processed. Consistently, oocyte culling in AZTtreated fetal ovaries now occurs in the early postnatal period (Fig. 3; Malki et al. 2014), during the diploteneto-dictyate transition when programmed DSBs have mostly been repaired and cells become sensitive to DNA damage-induced apoptosis (Hanoux et al. 2007). This observation raises the possibility that L1-induced DNA lesions are not efficiently repaired by the meiotic recombination machinery, or that some other AZT-independent activity of L1 interferes with meiotic DSB repair.

\section{Advantages of EOA}

In early meiotic prophase, the high background of ongoing DSB repair may make it unfeasible for oocytes to monitor L1 activity based on L1-inflicted DNA damage. The ability of oocytes to detect excessive L1 activity independently of DNA damage overcomes this challenge, enabling selective early culling of oocytes with high L1 activity. Despite the associated payoff of massive oocyte loss, follicles selected for low L1 activity likely experience a several-fold advantage because they have (i) a lower probability to experience de novo insertion; (ii) fewer SPO11-independent DSBs that could lead to LOA and other defects (see below) (Carofiglio et al. 2013; Rinaldi et al. 2017a); (iii) fewer synapsis defects and associated meiotic silencing, which can also cause oocyte death (see below) (Royo et al. 2013); (iv) higher crossover levels and thus a lower chance of homolog missegregation at meiosis I and aneuploidy in the resulting zygote; (v) a lower probability to transmit L1 RNA to the zygote and inflict insertion during embryogenesis (Kano et al. 2009); and (vi) possibly, a higher capacity to silence L1 postnatally and in the next generation. It should be noted that EOA occurs around the time of cytoplasmic transfer between interconnected sister oocytes and the breakdown of cysts (Lei and Spradling 2013, 2016). The relationship between the level of L1 activity and the differentiation of oocytes that will survive and the nurse cells that will nurture them and then die is unknown and an important question for the future.

\section{Potential Advantages of L1 Derepression in the Germline}

It is also speculated that DNA demethylation and the resulting derepression of $\mathrm{L} 1$ elements play positive roles for germ cell differentiation, meiosis, and genotype diversity during development (Kano et al. 2009; van der Heijden and Bortvin 2009; Castañeda et al. 2011; Chuma 2014; Malki et al. 2014). For example, transcriptional regulation mediated by insertionally inactive L1 elements could be important for the meiotic program. The sheer abundance of L1 elements and their enriched association with chromosome axes and SCs (Pearlman et al. 1992; Hernández-Hernández et al. 2008) raises the possibility they help organize meiotic chromosome structure and facilitate homolog recognition and pairing (van der Heijden and Bortvin 2009).

\section{DNA DAMAGE AND SYNAPSIS DEFECTS TRIGGER LOA}

LOA was originally delineated in meiotic mutants defective for DSB repair and/or homolog synapsis (Di Giacomo et al. 2005). Such mutants are typically born with large oocyte pools (at least $50 \%$ of wild type), which rapidly decline in the first few days after birth, as cells transition into the dictyate stage, arrest, and establish the reserve of primordial follicles (Di Giacomo et al. 2005; Kogo et al. 2012a; Wojtasz et al. 2012; Kerr et al. 2013; Bolcun-Filas et al. 2014; Malki et al. 2014; Cloutier et al. 2015; Rinaldi et al. 2017a; Hunter N, unpubl. data). The severity of LOA can vary between mutants. For example, in Spo11 mutants, which lack programmed DSBs, chromosome synapsis is severely defective, but $\sim 15 \%$ of oocytes survive LOA. However, this small reserve is rapidly depleted because of recruitment, ensuing atresia, and ovulation (Di Giacomo et al. 2005). In contrast, in mutants such as Dmc1, Msh4, Msh5, Atm, Trip13, and $M c m d c 2$, recombination is initiated, but DSB repair and/ or synapsis are defective, and wholesale culling of oocytes is observed within 2-5 d of birth (Di Giacomo et al. 2005; Li and Schimenti 2007; Finsterbusch et al. 2016; McNairn et al. 2017; Hunter N, unpubl. data). Spo11 mutation is epistatic to DSB repair mutants with respect to the severity of oocyte loss, indicating that defective repair of SPO11dependent DSBs is a potent trigger of LOA.

\section{A Single DNA Damage Response Pathway May Trigger LOA Caused by Meiotic Defects}

The observations described above led to the concept of two distinct checkpoint processes that can lead to LOA, one that monitors DSB repair and another that responds to defective synapsis (Di Giacomo et al. 2005; Wojtasz et al. 2012; Bolcun-Filas et al. 2014; Cloutier et al. 2015). However, more recent studies have revealed the existence of a significant population of SPO11-independent DSBs that can also trigger oocyte death via the DNA damage response (Carofiglio et al. 2013; Rinaldi et al. 2017a). This class of DSBs is highly variable in number, mirroring the variable expression of the L1ORF1 protein and consistent with the idea that a possible source of SPO11-independent DSBs is DNA cleavage initiated by the L1ORF2 endonuclease (Malki et al. 2014). Thus, a single pathway that signals persistent DNA breaks, regardless of their cause, may account for the majority of LOA (Rinaldi et al. 2017a). This meiotic DNA damage response pathway is mediated by a chromosome axis-based, kinasesignaling cascade whose key components include the proximal kinase ATR and the effector kinase CHK2 (Fig. 4; Bolcun-Filas et al. 2014; Subramanian and Hochwagen 2014; Rinaldi et al. 2017a). CHK2 activates the apoptotic regulators $\mathrm{p} 53$ and an isoform of p63 (a p53 paralog) called TAp63 (the Trans-Activation isoform), which appear to trigger apoptosis through canonical pathways (Morita et al. 1999; Kerr et al. 2012; Bolcun-Filas et al. 2014; Klinger et al. 2015; Omari et al. 2015). TAp63 is first expressed in late pachytene and diplotene oocytes and re- 


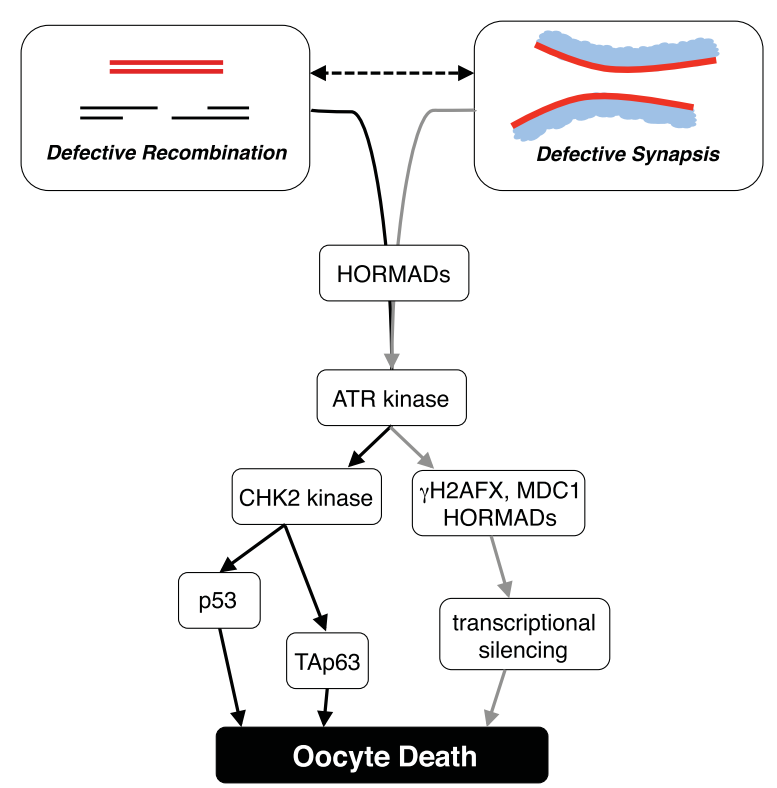

Figure 4. Meiotic DNA damage response and transcriptional silencing pathways. Double-strand breaks and defective synapsis are signaled via the HORMADs and the ATR kinase. ATR activates the effector kinase CHK2 to induce apoptosis via p53 and TAp63. ATR also mediates transcriptional silencing by nucleating and amplifying H2AFX phosphorylation in conjunction with MCD1 and the HORMAD proteins. The dashed line indicates the interdependence between defective recombination and defective chromosome synapsis.

mains constitutively expressed in resting follicles conferring exquisite sensitivity to DNA damage (Suh et al. 2006; Livera et al. 2008; Bolcun-Filas et al. 2014; Kim and Suh 2014). p53 may be the primary mediator of apoptosis during the diplotene-to-dictyate transition, with TAp63 largely superseding this function in quiescent oocytes. However, a more complex regulatory relationship between p53 and TAp63 is also suggested (Bolcun-Filas et al. 2014).

A key observation implicating the meiotic DNA damage response in LOA is the striking rescue of oocyte death and infertility in Trip 13 mutant females by Chk2 mutation (Bolcun-Filas et al. 2014). However, rescue is incomplete, suggesting that other kinases may partially substitute for CHK2 function, especially when residual DSB levels are high; candidates include CHK1, DNA-PK, or direct signaling by ATR or the related PI3K-like kinase, ATM. Notably, the efficiency of oocyte rescue by $C h k 2$ mutation negatively correlates with the number of residual DSBs present in different mutant backgrounds and/or as a result of ionizing irradiation (Rinaldi et al. 2017a). These observations point to a damage-threshold model for oocyte elimination in which oocytes with at least 10 residual DSBs are culled.

\section{Meiosis-Specific HORMA-Domain Proteins Facilitate LOA}

Other key players in LOA include HORMAD1 and HORMAD2, two members of a conserved family of meiosis-specific HORMA (Hop1, Rev7, and Mad2)domain proteins (HORMADs) (Daniel et al. 2011; Kogo et al. 2012b; Shin et al. 2013). HORMADs play central roles in regulating the major events of meiotic prophase-I, including meiotic DSB formation, homolog pairing, and synapsis, checkpoint signaling, transcriptional silencing (described below), and biasing meiotic recombination to occur between homologs by impeding intersister DSB repair (Carballo et al. 2008; Shin et al. 2010; Royo et al. 2013; Vader and Musacchio 2014; Stanzione et al. 2016; Rinaldi et al. 2017a). As discussed below, the latter two functions appear to be central to the role of the HORMADs in promoting LOA (Rinaldi et al. 2017a; Hunter N, unpubl. results).

HORMADs initially associate with unsynapsed chromosome axes during leptotene but are locally depleted at regions of synapsis during zygotene and excluded from fully synapsed chromosomes during pachytene (Fig. 5; Wojtasz et al. 2009; Fukuda et al. 2010). By analogy to the orthologous budding yeast Hop1 protein (Niu et al. 2005; Carballo et al. 2008; Goldfarb and Lichten 2010; Lao and Hunter 2010), and supported by indirect evidence, mammalian HORMADs are inferred to function in early meiotic prophase to impede DSB repair between sister chromatids and thereby promote interhomolog interactions (Fig. 6; Daniel et al. 2011; Kogo et al. 2012b; Shin et al. 2013; Rinaldi et al. 2017a). HORMAD depletion is coupled to synapsis via the AAA+ ATPase, TRIP13 (a.k.a. PCH2 in nonmammalian species) (Li and Schimenti 2007; Wojtasz et al. 2009; Roig et al. 2010), which likely disrupts protein-protein interactions at the homolog axis, including the ability of HORMADs to oligomerize (Ye et al. 2017; West et al. 2018). In asynaptic mutants and when TRIP13 function is compromised, HORMADs remain associated with the homolog axes and impede DSB repair (Fukuda et al. 2010; Shin et al. 2010; Daniel et al. 2011; Shin et al. 2013; Rinaldi et al. 2017a). Thus, oocyte culling in mutants defective for homolog synapsis and DSB repair can be suppressed to varying degrees by mutation of Hormadl or Hormad2 (Daniel et al. 2011; Kogo et al. 2012b; Shin et al. 2013; Rinaldi et al. 2017a). However, the mode of suppression by Hormad1/2 mutation appears to be distinct from that of Chk2 and p53/TAp63 mutations.

The high levels of DNA damage that persist in dictyatestage oocytes from Chk2 Trip13 double mutants are consistent with $\mathrm{CHK} 2$ acting as a bona fide checkpoint protein, allowing cells to progress but not affecting the efficiency of DSB repair (Bolcun-Filas et al. 2014). However, this damage is subsequently repaired, oocytes remain viable, and Chk2 Trip 13 mutants are fertile. This contrasts the effects of Hormad1/2 mutation, which decrease DSB levels and accelerate DSB repair (Fukuda et al. 2010; Shin et al. 2010; Daniel et al. 2011; Shin et al. 2013; Rinaldi et al. 2017a). HORMAD1 has a twofold effect on DSB levels, facilitating the formation of SPO11-dependent DSB and impeding their repair until homologs have synapsed. HORMAD2 shares only the latter function and its localization to unsynapsed chromosome axes requires HORMAD1. Thus, absence of HORMADs is inferred to reduce DSB load (Hormad1 mutation) and enhance DSB-repair capacity (Hormad1 and Hormad2 mutations) by allowing recombination between sister chromatids such that damage signaling is diminished 

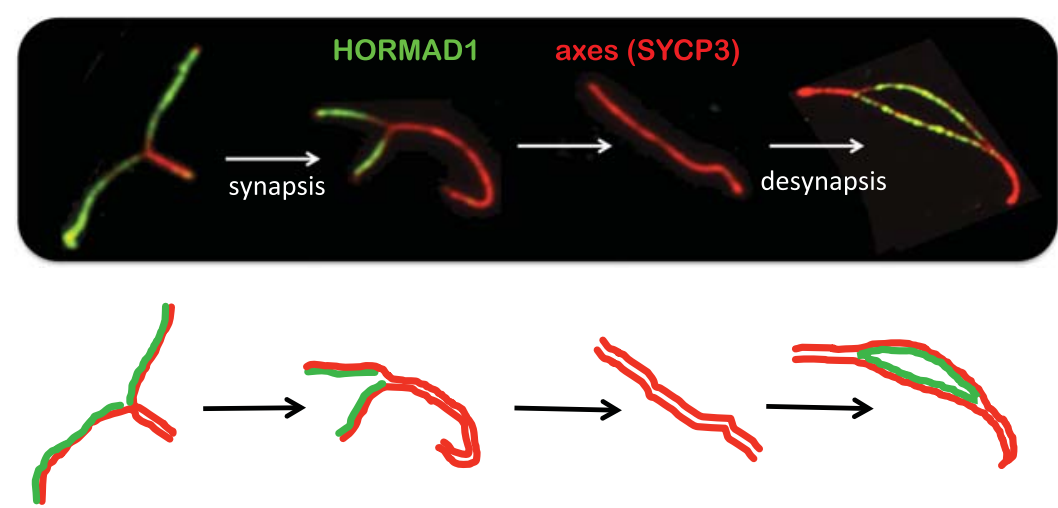

Figure 5. Dynamic localization of HORMADs during meiotic prophase I. Images show mouse oocyte chromosomes immunostained for the axes marker SYCP3 and HORMAD1.

(Daniel et al. 2011; Kogo et al. 2012b; Shin et al. 2013; Rinaldi et al. 2017a). Put another way, by blocking the repair of DSBs between sister chromatids, HORMADs help maintain damage signaling at levels required to trigger LOA. These observations indicate that CHK2 and the HORMAD proteins collaborate to signal defective interhomolog interactions and trigger LOA (Fig. 4).

\section{Meiotic Silencing Is Mediated by HORMADs and Components of the DNA Damage Response}

Chromosome asynapsis in Spoll mutants, and in a variety of other contexts that cause partial asynapsis, also triggers a distinct response termed meiotic silencing that results in transcriptional inactivation and is inferred to contribute to oocyte death by silencing genes required for survival (Mahadevaiah et al. 2008; Burgoyne et al. 2009; Garcia-Cruz et al. 2009; Kouznetsova et al. 2009; Blanco-Rodríguez 2012; Royo et al. 2013; Cloutier et al. 2015; Turner 2015). Sensing of asynapsis involves homolog axis components, the HORMAD proteins, and BRCA1. ATR and its activators ATRIP and TOPBP1 are then recruited to establish a reversible asynapsis signaling step that involves phosphorylation of the HORMADs (Fukuda et al. 2012; Royo et al. 2013). Silencing initiates via the ATR-catalyzed phosphorylation the histone variant H2AFX. This $\gamma \mathrm{H} 2 \mathrm{AFX}$ mark spreads throughout the unsynapsed region via a signal-amplification step mediated by ATR, HORMADs, and the $\gamma \mathrm{H} 2 \mathrm{AFX}$ binding factor

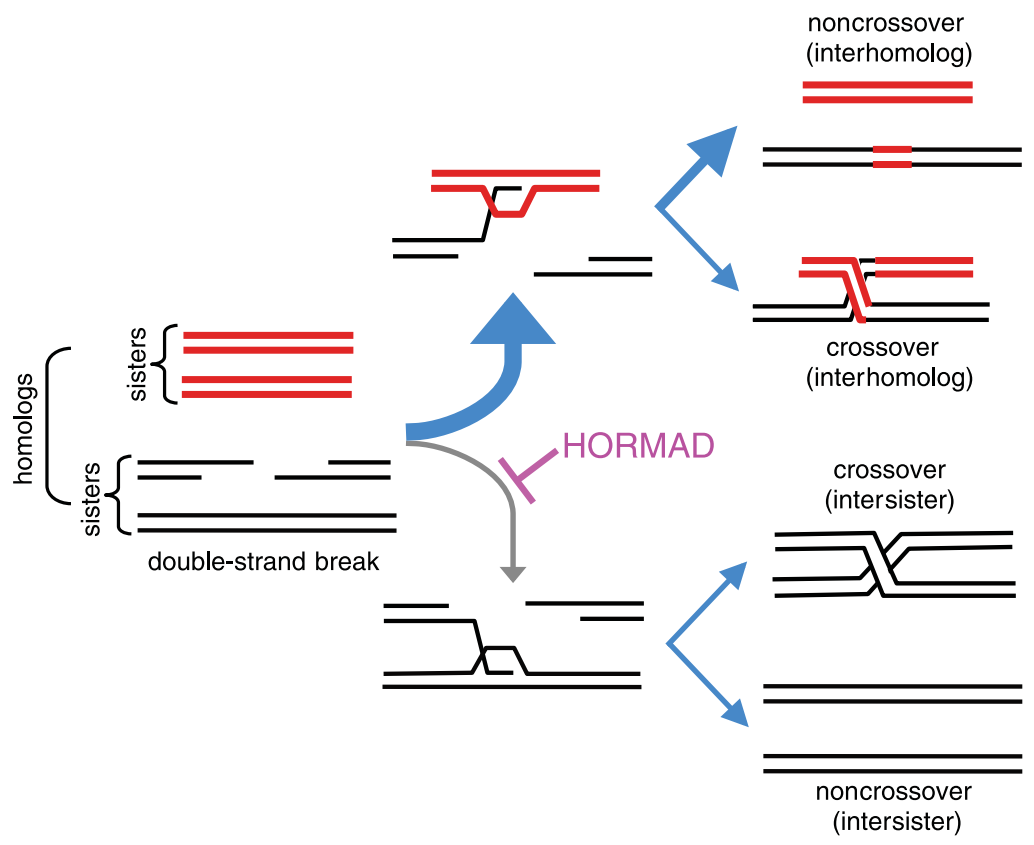

Figure 6. HORMADs bias recombination to occur between homologs rather than sister chromatids. Meiotic recombination must occur between homologs to achieve pairing, synapsis, and crossing-over. HORMADs promote interhomolog interactions through unknown mechanisms. One model posits that HORMADs create a barrier to intersister recombination (Hollingsworth 2010). Alternatively, HORMADs may prevent recombination from progressing beyond the initial nascent DNA strand-exchange step and couple progression to homolog synapsis (Goldfarb and Lichten 2010; Lao and Hunter 2010). 
MDC1 (Ichijima et al. 2011; Kogo et al. 2012a). Ensuing heterochromatinization results in exclusion of RNA Pol II. Persistent DSBs within unsynapsed regions, both SPO11dependent and independent, are thought to serve as initiation sites for meiotic silencing (Carofiglio et al. 2013; ElInati et al. 2017). However, the enrichment of DSB markers observed within silenced regions is also likely to reflect the inhibitory role of HORMADs on DSB repair.

\section{Physiological LOA and the Role of HORMADs}

LOA was defined and is typically studied in a variety of pathological conditions that cause severe defects in DSB repair and/or synapsis and wholesale oocyte death. In these settings, initial association of HORMADs persists and promotes oocyte death by impeding DSB repair between sister chromatids (Rinaldi et al. 2017a). In contrast, in a physiological setting, DSBs engage in interhomolog interactions, synapsis generally occurs efficiently, and HORMADs dissociate, presumably enabling recombination to progress. HORMADs then reassociate with desynapsing homolog axes during diplonema when DSBs have been repaired and crossing-over has occurred (Fig. 5; Fukuda et al. 2010; Niu et al. 2005; Wojtasz et al. 2009). The role of HORMADs at this stage is unknown, but a role in signaling recombination defects can be envisioned. Residual DSBs present in diplotene may be the result of failed interhomolog recombination or de novo DSB formation (e.g., via L1 activity or aberrant processing of recombination intermediates by nucleases). Reassociation of HORMADs at this stage could block intersister repair to robustly signal such defects and enable a quality control decision to be made. Nascent meiotic silencing events could also be reinforced by HORMAD reloading. Thus, the reassociation of HORMADs is potentially a key event that primes oocytes for LOA specifically during the diplotene-to-dictyate transition and may explain why oocytes become sensitive to irradiationinduced apoptosis at this time (Hanoux et al. 2007; Hunter $\mathrm{N}$, unpubl. data). Other events that may potentiate LOA during this transition include the onset of expression and ability to activate apoptotic factors, including TAp63 and caspase 2 (Suh et al. 2006; Hanoux et al. 2007; Livera et al. 2008; Kim and Suh 2014). Consequently, oocytes that have experienced defects in synapsis and/or recombination are eliminated before they become established in the ovarian reserve as primordial follicles, thereby minimizing nonproductive ovulation and the risk of meiotic errors.

\section{CONCLUSION}

Oocyte attrition occurs in response to L1 activity, meiotic errors, and self-sacrifice of nurse-like cells. These processes are estimated to cull up to $80 \%$ of all oocytes in mouse (Malki et al. 2014; Hunter N, unpubl. data), mirroring the dramatic reduction in oocyte numbers seen in human females between 20 wk gestation and birth (Findlay et al. 2015). Thus, oocyte attrition in human females is presumed to occur via equivalent quality control processes. However, significant differences likely exist. For example, numbers of full-length, potentially mobile L1 elements differ between mouse and human, with an estimated 11,000 in mouse compared to just 100 in human (Goodier and Kazazian 2008). As such, the L1 load may be lower in humans. An important goal for the future is to attain a clearer understanding of the causes and mechanisms of oocyte culling in humans or nonhuman primates.

Studies of EOA and LOA described here raise many burning questions. What are the relationships between L1 expression, meiotic errors, and oocyte/nurse cell differentiation? Is EOA triggered by L1-mediated RNA: DNA hybrids and, if so, what is the mechanism? Does EOA occur via apoptosis or an alternative cell death pathway? Why is L1 expression so variable between oocytes and what factors influence this ostensibly cellautonomous phenomenon? What is the contribution of the various suppressive mechanisms to L1 inhibition during meiosis? Does the L1ORF2 reverse-transcriptase activity interfere with crossing-over, and, if so, does this activity contribute to the crossover maturation defect seen in human females? Is L1ORF2 endonuclease activity responsible for SPO11-independent DSBs? What are the contributions of L1-dependent and independent prophase defects to LOA and to meiotic errors in oocytes that escape EOA? Can genetic and environmental factors be identified that specifically influence EOA and LOA? Is L1-regulated gene expression important for mammalian meiosis? Does treatment with reverse-transcriptase inhibitors during pregnancy impact EOA in humans? Do kinases other than CHK2 contribute to physiological LOA? What is the contribution of meiotic silencing to physiological LOA? How do HORMAD proteins impede DSB repair? How does synapsis trigger HORMAD dissociation and how are they reloaded onto diplotene chromosomes? Finally, can ovarian reserves be enlarged to extend reproductive life span, or can they be rescued from death induced by cancer therapeutic agents without sacrificing oocyte quality, fertility, and ovary function (Livera et al. 2008; Kerr et al. 2012; Bolcun-Filas et al. 2014; Rinaldi et al. 2017b)?

Despite these oocyte quality control processes, errors in meiosis are the leading cause of pregnancy miscarriage and congenital disease in humans (Hassold et al. 2007; Nagaoka et al. 2012; Hunter 2015). By interfering with the normal processes of meiotic prophase, the activities of L1 and other retroelements represent one source of meiotic errors. L1 insertion also poses a tangible threat to genomic integrity: The rate of insertion is estimated at greater than one in eight births in laboratory mice (Richardson et al. 2017), and at approximately one in 20 births in the humans (Kazazian 1999). Thus, it remains important to better understand the causes of meiotic errors, the processes that work to minimize them, and the quality-control processes that selectively eliminate defective gametes and nurture and protect those that survive.

\section{ACKNOWLEDGMENTS}

We thank Alex Bortvin, Ewelina Bolcun-Filas, Vera Rinaldi, John Schimenti, James Turner, and members of 
my laboratory for enlightening discussions. Research in my laboratory is supported by the Howard Hughes Medical Institute and the National Institutes of Health National Institute of General Medical Sciences (NIH NIGMS) under award GM074223.

\section{REFERENCES}

Aiken CE, Tarry-Adkins JL, Ozanne SE. 2015. Transgenerational developmental programming of ovarian reserve. Sci Rep 5: 16175 .

Aravin AA, Sachidanandam R, Bourc'his D, Schaefer C, Pezic D, Toth KF, Bestor T, Hannon GJ. 2008. A piRNA pathway primed by individual transposons is linked to de novo DNA methylation in mice. Mol Cell 31: 785-799.

Athanikar JN, Badge RM, Moran JV. 2004. AYY1-binding site is required for accurate human LINE-1 transcription initiation. Nucleic Acids Res 32: 3846-3855.

Babushok DV, Kazazian HH Jr. 2007. Progress in understanding the biology of the human mutagen LINE-1. Hum Mutat 28: 527-539.

Baker TG. 1963. A quantitative and cytological study of germ cells in human ovaries. Proc R Soc Lond B Biol Sci 158: 417-433.

Beck CR, Garcia-Perez JL, Badge RM, Moran JV. 2011. LINE-1 elements in structural variation and disease. Annu Rev Genomics Hum Genet 12: 187-215.

Belancio VP, Hedges DJ, Deininger P. 2006. LINE-1 RNA splicing and influences on mammalian gene expression. Nucleic Acids Res 34: 1512-1521.

Belancio VP, Roy-Engel AM, Deininger P. 2008. The impact of multiple splice sites in human L1 elements. Gene 411: 38-45.

Belgnaoui SM, Gosden RG, Semmes OJ, Haoudi A. 2006. Human LINE-1 retrotransposon induces DNA damage and apoptosis in cancer cells. Cancer Cell Int 6: 13.

Blanco-Rodríguez J. 2012. Programmed phosphorylation of histone H2AX precedes a phase of DNA double-strand break-independent synapsis in mouse meiosis. Reproduction 144: 699-712.

Block E. 1953. A quantitative morphological investigation of the follicular system in newborn female infants. Acta Anat (Basel) 17: 201-206.

Bolcun-Filas E, Rinaldi VD, White ME, Schimenti JC. 2014. Reversal of female infertility by Chk2 ablation reveals the oocyte DNA damage checkpoint pathway. Science 343: 533-536.

Bourc'his D, Bestor TH. 2004. Meiotic catastrophe and retrotransposon reactivation in male germ cells lacking Dnmt3L. Nature 431: 96-99.

Broekmans FJ, Knauff EA, te Velde ER, Macklon NS, Fauser BC. 2007. Female reproductive ageing: Current knowledge and future trends. Trends Endocrinol Metab 18: 58-65.

Brouha B, Schustak J, Badge RM, Lutz-Prigge S, Farley AH, Moran JV, Kazazian HH Jr. 2003. Hot L1s account for the bulk of retrotransposition in the human population. Proc Natl Acad Sci 100: 5280-5285.

Burgoyne PS, Mahadevaiah SK, Turner JM. 2009. The consequences of asynapsis for mammalian meiosis. Nat Rev Genet 10: $207-216$.

Carballo JA, Johnson AL, Sedgwick SG, Cha RS. 2008. Phosphorylation of the axial element protein Hop1 by Mec1/Tel1 ensures meiotic interhomolog recombination. Cell 132: 758 770 .

Carofiglio F, Inagaki A, de Vries S, Wassenaar E, Schoenmakers $\mathrm{S}$, Vermeulen C, van Cappellen WA, Sleddens-Linkels E, Grootegoed JA, Te Riele HP, et al. 2013. SPO11-independent DNA repair foci and their role in meiotic silencing. PLoS Genet 9: e1003538.

Castañeda J, Genzor P, Bortvin A. 2011. piRNAs, transposon silencing, and germline genome integrity. Mutat Res 714: 95-104.

Cheng EY, Hunt PA, Naluai-Cecchini TA, Fligner CL, Fujimoto VY, Pasternack TL, Schwartz JM, Steinauer JE, Woodruff TJ,
Cherry SM, et al. 2009. Meiotic recombination in human oocytes. PLoS Genet 5: e1000661.

Chuma S. 2014. LINE-1 of evidence for fetal oocyte attrition by retrotransposon. Dev Cell 29: 501-502.

Cloutier JM, Mahadevaiah SK, ElInati E, Nussenzweig A, Tóth A, Turner JM. 2015. Histone H2AFX links meiotic chromosome asynapsis to prophase I oocyte loss in mammals. PLoS Genet 11: e1005462.

Cole F, Kauppi L, Lange J, Roig I, Wang R, Keeney S, Jasin M. 2012. Homeostatic control of recombination is implemented progressively in mouse meiosis. Nat Cell Biol 14: 424-430.

Cordaux R, Batzer MA. 2009. The impact of retrotransposons on human genome evolution. Nat Rev Genet 10: 691-703.

Cost GJ, Feng Q, Jacquier A, Boeke JD. 2002. Human L1 element target-primed reverse transcription in vitro. $E M B O J$ 21: $5899-5910$.

Crow MK. 2010. Long interspersed nuclear elements (LINE-1): Potential triggers of systemic autoimmune disease. Autoimmunity 43: 7-16.

Dai L, Huang Q, Boeke JD. 2011. Effect of reverse transcriptase inhibitors on LINE-1 and Ty1 reverse transcriptase activities and on LINE-1 retrotransposition. BMC Biochem 12: 18.

Daniel K, Lange J, Hached K, Fu J, Anastassiadis K, Roig I, Cooke HJ, Stewart AF, Wassmann K, Jasin M, et al. 2011. Meiotic homologue alignment and its quality surveillance are controlled by mouse HORMAD1. Nat Cell Biol 13: 599-610.

Dekker J, Mirny L. 2016. The 3D genome as moderator of chromosomal communication. Cell 164: 1110-1121.

Dewannieux M, Esnault C, Heidmann T. 2003. LINE-mediated retrotransposition of marked Alu sequences. Nat Genet 35: 41-48.

Di Giacomo M, Barchi M, Baudat F, Edelmann W, Keeney S, Jasin M. 2005. Distinct DNA-damage-dependent and -independent responses drive the loss of oocytes in recombination-defective mouse mutants. Proc Natl Acad Sci 102: 737-742.

ElInati E, Russell HR, Ojarikre OA, Sangrithi M, Hirota T, de Rooij DG, McKinnon PJ, Turner JMA. 2017. DNA damage response protein TOPBP1 regulates $\mathrm{X}$ chromosome silencing in the mammalian germ line. Proc Natl Acad Sci 114: 1253612541.

Esnault C, Maestre J, Heidmann T. 2000. Human LINE retrotransposons generate processed pseudogenes. Nat Genet 24: 363-367.

Faulkner GJ, Kimura Y, Daub CO, Wani S, Plessy C, Irvine KM, Schroder K, Cloonan N, Steptoe AL, Lassmann T, et al. 2009. The regulated retrotransposon transcriptome of mammalian cells. Nat Genet 41: 563-571.

Findlay JK, Hutt KJ, Hickey M, Anderson RA. 2015. How is the number of primordial follicles in the ovarian reserve established? Biol Reprod 93: 111.

Finsterbusch F, Ravindranathan R, Dereli I, Stanzione M, Tränkner D, Tóth A. 2016. Alignment of homologous chromosomes and effective repair of programmed DNA double-strand breaks during mouse meiosis require the minichromosome maintenance domain containing 2 (MCMDC2) protein. PLoS Genet 12: e1006393.

Forabosco A, Sforza C, De Pol A, Vizzotto L, Marzona L, Ferrario VF. 1991. Morphometric study of the human neonatal ovary. Anat Rec 231: 201-208.

Fukuda T, Daniel K, Wojtasz L, Toth A, Höög C. 2010. A novel mammalian HORMA domain-containing protein, HORMAD1, preferentially associates with unsynapsed meiotic chromosomes. Exp Cell Res 316: 158-171.

Fukuda T, Pratto F, Schimenti JC, Turner JM, Camerini-Otero RD, Höög C. 2012. Phosphorylation of chromosome core components may serve as axis marks for the status of chromosomal events during mammalian meiosis. PLoS Genet 8: e1002485.

Garcia-Cruz R, Roig I, Robles P, Scherthan H, Garcia Caldés M. 2009. ATR, BRCA1 and gammaH2AX localize to unsynapsed chromosomes at the pachytene stage in human oocytes. Reprod Biomed Online 18: 37-44. 
Gasior SL, Wakeman TP, Xu B, Deininger PL. 2006. The human LINE-1 retrotransposon creates DNA double-strand breaks. $J$ Mol Biol 357: 1383-1393.

Gasior SL, Roy-Engel AM, Deininger PL. 2008. ERCC1/XPF limits L1 retrotransposition. DNA Repair (Amst) 7: 983-989.

Gleicher N, Weghofer A, Barad DH. 2011. Defining ovarian reserve to better understand ovarian aging. Reprod Biol Endocrinol 9: 23.

Goldfarb T, Lichten M. 2010. Frequent and efficient use of the sister chromatid for DNA double-strand break repair during budding yeast meiosis. PLoS Biol 8: e1000520.

Goodier JL. 2016. Restricting retrotransposons: A review. Mob DNA 7: 16.

Goodier JL, Kazazian HH Jr. 2008. Retrotransposons revisited: The restraint and rehabilitation of parasites. Cell 135: 23-35.

Goodier JL, Pereira GC, Cheung LE, Rose RJ, Kazazian HH Jr. 2015. The broad-spectrum antiviral protein ZAP restricts human retrotransposition. PLoS Genet 11: e1005252.

Grandi FC, An W. 2013. Non-LTR retrotransposons and microsatellites: Partners in genomic variation. Mob Genet Elements 3: 225674 .

Grive KJ, Freiman RN. 2015. The developmental origins of the mammalian ovarian reserve. Development 142: 2554-2563.

Gruhn JR, Rubio C, Broman KW, Hunt PA, Hassold T. 2013. Cytological studies of human meiosis: Sex-specific differences in recombination originate at, or prior to, establishment of double-strand breaks. PLoS One 8: e85075.

Hamdorf M, Idica A, Zisoulis DG, Gamelin L, Martin C, Sanders KJ, Pedersen IM. 2015. miR-128 represses L1 retrotransposition by binding directly to L1 RNA. Nat Struct Mol Biol 22: 824-831.

Han JS, Szak ST, Boeke JD. 2004. Transcriptional disruption by the L1 retrotransposon and implications for mammalian transcriptomes. Nature 429: 268-274.

Hanoux V, Pairault C, Bakalska M, Habert R, Livera G. 2007. Caspase-2 involvement during ionizing radiation-induced oocyte death in the mouse ovary. Cell Death Differ 14: 671-681.

Hansen AS, Cattoglio C, Darzacq X, Tjian R. 2018. Recent evidence that TADs and chromatin loops are dynamic structures. Nucleus 9: 20-32.

Hartshorne GM, Lyrakou S, Hamoda H, Oloto E, Ghafari F. 2009. Oogenesis and cell death in human prenatal ovaries: What are the criteria for oocyte selection? Mol Hum Reprod 15: $805-819$.

Hassold T, Hunt P. 2001. To err (meiotically) is human: The genesis of human aneuploidy. Nat Rev Genet 2: 280-291.

Hassold T, Hall H, Hunt P. 2007. The origin of human aneuploidy: Where we have been, where we are going. Hum Mol Genet 16: R203-R208.

Hata K, Sakaki Y. 1997. Identification of critical CpG sites for repression of L1 transcription by DNA methylation. Gene 189: 227-234.

Herbert M, Kalleas D, Cooney D, Lamb M, Lister L. 2015. Meiosis and maternal aging: Insights from aneuploid oocytes and trisomy births. Cold Spring Harb Perspect Biol 7: a017970.

Hernández-Hernández A, Rincón-Arano $\mathrm{H}$, Recillas-Targa F, Ortiz R, Valdes-Quezada C, Echeverría OM, Benavente R, Vázquez-Nin GH. 2008. Differential distribution and association of repeat DNA sequences in the lateral element of the synaptonemal complex in rat spermatocytes. Chromosoma 117: 77-87.

Hollingsworth NM. 2010. Phosphorylation and the creation of interhomolog bias during meiosis in yeast. Cell Cycle 9: 436437.

Honour JW. 2018. Biochemistry of the menopause. Ann Clin Biochem 55: 18-33.

Hu S, Li J, Xu F, Mei S, Le Duff Y, Yin L, Pang X, Cen S, Jin Q, Liang C, et al. 2015. SAMHD1 Inhibits LINE-1 Retrotransposition by Promoting Stress Granule Formation. PLoS Genet 11: e1005367.

Hunt PA, Hassold TJ. 2008. Human female meiosis: What makes a good egg go bad? Trends Genet 24: 86-93.
Hunter N. 2015. Meiotic recombination: The essence of heredity. Cold Spring Harb Perspect Biol 7: a016618.

Ichijima Y, Ichijima M, Lou Z, Nussenzweig A, Camerini-Otero RD, Chen J, Andreassen PR, Namekawa SH. 2011. MDC1 directs chromosome-wide silencing of the sex chromosomes in male germ cells. Genes Dev 25: 959-971.

Izquierdo-Bouldstridge A, Bustillos A, Bonet-Costa C, AribauMiralbés P, García-Gomis D, Dabad M, Esteve-Codina A, Pascual-Reguant L, Peiró S, Esteller M, et al. 2017. Histone $\mathrm{H} 1$ depletion triggers an interferon response in cancer cells via activation of heterochromatic repeats. Nucleic Acids Res 45: $11622-11642$.

Jenkins VK, Timmons AK, McCall K. 2013. Diversity of cell death pathways: Insight from the fly ovary. Trends Cell Biol 23: $567-574$

Jones RB, Garrison KE, Wong JC, Duan EH, Nixon DF, Ostrowski MA. 2008. Nucleoside analogue reverse transcriptase inhibitors differentially inhibit human LINE-1 retrotransposition. PLoS One 3: e1547.

Kaipia A, Hsueh AJ. 1997. Regulation of ovarian follicle atresia. Annu Rev Physiol 59: 349-363.

Kano H, Godoy I, Courtney C, Vetter MR, Gerton GL, Ostertag EM, Kazazian HH Jr. 2009. L1 retrotransposition occurs mainly in embryogenesis and creates somatic mosaicism. Genes Dev 23: 1303-1312.

Kazazian HH Jr. 1999. An estimated frequency of endogenous insertional mutations in humans. Nat Genet 22: 130.

Kerr JB, Hutt KJ, Michalak EM, Cook M, Vandenberg CJ, Liew SH, Bouillet P, Mills A, Scott CL, Findlay JK, et al. 2012. DNA damage-induced primordial follicle oocyte apoptosis and loss of fertility require TAp63-mediated induction of Puma and Noxa. Mol Cell 48: 343-352.

Kerr JB, Myers M, Anderson RA. 2013. The dynamics of the primordial follicle reserve. Reproduction 146: R205-R215.

Kim DA, Suh EK. 2014. Defying DNA double-strand breakinduced death during prophase I meiosis by temporal TAp63 $\alpha$ phosphorylation regulation in developing mouse oocytes. Mol Cell Biol 34: 1460-1473.

Klinger FG, Rossi V, De Felici M. 2015. Multifaceted programmed cell death in the mammalian fetal ovary. Int $J$ Dev Biol 59: 51-54.

Kogo H, Tsutsumi M, Inagaki H, Ohye T, Kiyonari H, Kurahashi H. 2012a. HORMAD2 is essential for synapsis surveillance during meiotic prophase via the recruitment of ATR activity. Genes Cells 17: 897-912.

Kogo H, Tsutsumi M, Ohye T, Inagaki H, Abe T, Kurahashi H. 2012b. HORMAD1-dependent checkpoint/surveillance mechanism eliminates asynaptic oocytes. Genes Cells 17: 439-454.

Kouznetsova A, Wang H, Bellani M, Camerini-Otero RD, Jessberger R, Höög C. 2009. BRCA1-mediated chromatin silencing is limited to oocytes with a small number of asynapsed chromosomes. J Cell Sci 122: 2446-2452.

Kuramochi-Miyagawa S, Watanabe T, Gotoh K, Totoki Y, Toyoda A, Ikawa M, Asada N, Kojima K, Yamaguchi Y, Ijiri TW, et al. 2008. DNA methylation of retrotransposon genes is regulated by Piwi family members MILI and MIWI2 in murine fetal testes. Genes Dev 22: 908-917.

Kurilo LF. 1981. Oogenesis in antenatal development in man. Hum Genet 57: 86-92.

Lam I, Keeney S. 2014. Mechanism and regulation of meiotic recombination initiation. Cold Spring Harb Perspect Biol 7: a016634.

Lao JP, Hunter N. 2010. Trying to avoid your sister. PLoS Biol 8: e1000519.

Laven JS. 2015. Genetics of early and normal menopause. Semin Reprod Med 33: 377-383.

Laven JS. 2016. Primary ovarian insufficiency. Semin Reprod Med 34: 230-234.

Laven JSE, Visser JA, Uitterlinden AG, Vermeij WP, Hoeijmakers JHJ. 2016. Menopause: Genome stability as new paradigm. Maturitas 92: 15-23.

Lee JY, Ji Z, Tian B. 2008. Phylogenetic analysis of mRNA polyadenylation sites reveals a role of transposable elements 
in evolution of the $3^{\prime}$-end of genes. Nucleic Acids Res 36: 5581-5590.

Lei L, Spradling AC. 2013. Mouse primordial germ cells produce cysts that partially fragment prior to meiosis. Development 140: 2075-2081.

Lei L, Spradling AC. 2016. Mouse oocytes differentiate through organelle enrichment from sister cyst germ cells. Science 352: 95-99.

Lenzi ML, Smith J, Snowden T, Kim M, Fishel R, Poulos BK, Cohen PE. 2005. Extreme heterogeneity in the molecular events leading to the establishment of chiasmata during meiosis $\mathrm{i}$ in human oocytes. Am J Hum Genet 76: 112-127.

Li XC, Schimenti JC. 2007. Mouse pachytene checkpoint 2 (trip13) is required for completing meiotic recombination but not synapsis. PLoS Genet 3: e130.

Li P, Du J, Goodier JL, Hou J, Kang J, Kazazian HH Jr, Zhao K, Yu XF. 2017. Aicardi-Goutieres syndrome protein TREX1 suppresses L1 and maintains genome integrity through exonuclease-independent ORF1p depletion. Nucleic Acids Res 45: 4619-4631.

Liu N, Lee CH, Swigut T, Grow E, Gu B, Bassik MC, Wysocka J. 2018. Selective silencing of euchromatic L1s revealed by genome-wide screens for L1 regulators. Nature 553: 228-232.

Livera G, Petre-Lazar B, Guerquin MJ, Trautmann E, Coffigny H, Habert R. 2008. p63 null mutation protects mouse oocytes from radio-induced apoptosis. Reproduction 135: 3-12.

MacLennan M, García-Cañadas M, Reichmann J, Khazina E, Wagner G, Playfoot CJ, Salvador-Palomeque C, Mann AR, Peressini P, Sanchez L, et al. 2017. Mobilization of LINE-1 retrotransposons is restricted by Tex19.1 in mouse embryonic stem cells. eLife 6: e26152.

Mahadevaiah SK, Bourc'his D, de Rooij DG, Bestor TH, Turner JM, Burgoyne PS. 2008. Extensive meiotic asynapsis in mice antagonises meiotic silencing of unsynapsed chromatin and consequently disrupts meiotic sex chromosome inactivation. $J$ Cell Biol 182: 263-276.

Malki S, van der Heijden GW, O’Donnell KA, Martin SL, Bortvin A. 2014. A role for retrotransposon LINE-1 in fetal oocyte attrition in mice. Dev Cell 29: 521-533.

McGee EA, Hsueh AJ. 2000. Initial and cyclic recruitment of ovarian follicles. Endocr Rev 21: 200-214.

McNairn AJ, Rinaldi VD, Schimenti JC. 2017. Repair of meiotic DNA breaks and homolog pairing in mouse meiosis requires a minichromosome maintenance (MCM) paralog. Genetics 205: 529-537.

Messerschmidt DM, Knowles BB, Solter D. 2014. DNA methylation dynamics during epigenetic reprogramming in the germline and preimplantation embryos. Genes Dev 28: 812 828 .

Morita Y, Perez GI, Maravei DV, Tilly KI, Tilly JL. 1999. Targeted expression of Bcl-2 in mouse oocytes inhibits ovarian follicle atresia and prevents spontaneous and chemotherapy-induced oocyte apoptosis in vitro. Mol Endocrinol 13: 841-850.

Morrish TA, Gilbert N, Myers JS, Vincent BJ, Stamato TD, Taccioli GE, Batzer MA, Moran JV. 2002. DNA repair mediated by endonuclease-independent LINE-1 retrotransposition. Nat Genet 31: 159-165.

Nagaoka SI, Hassold TJ, Hunt PA. 2012. Human aneuploidy: Mechanisms and new insights into an age-old problem. Nat Rev Genet 13: 493-504.

Ng JH, Kumar V, Muratani M, Kraus P, Yeo JC, Yaw LP, Xue K, Lufkin T, Prabhakar S, Ng HH. 2013. In vivo epigenomic profiling of germ cells reveals germ cell molecular signatures. Dev Cell 24: 324-333.

Nigumann P, Redik K, Matlik K, Speek M. 2002. Many human genes are transcribed from the antisense promoter of L1 retrotransposon. Genomics 79: 628-634.

Niu H, Wan L, Baumgartner B, Schaefer D, Loidl J, Hollingsworth NM. 2005. Partner choice during meiosis is regulated by Hop1-promoted dimerization of Mek1. Mol Biol Cell 16: 5804-5818.

Omari S, Waters M, Naranian T, Kim K, Perumalsamy AL, Chi M, Greenblatt E, Moley KH, Opferman JT, Jurisicova A. 2015.
Mcl-1 is a key regulator of the ovarian reserve. Cell Death Dis 6: e1755.

Orecchini E, Frassinelli L, Galardi S, Ciafrè SA, Michienzi A. 2018. Post-transcriptional regulation of LINE-1 retrotransposition by AID/APOBEC and ADAR deaminases. Chromosome Res 26: 45-59.

Ostertag EM, Goodier JL, Zhang Y, Kazazian HH Jr. 2003. SVA elements are nonautonomous retrotransposons that cause disease in humans. Am J Hum Genet 73: 1444-1451.

Pearlman RE, Tsao N, Moens PB. 1992. Synaptonemal complexes from DNase-treated rat pachytene chromosomes contain $(\mathrm{GT})_{\mathrm{n}}$ and LINE/SINE sequences. Genetics 130: 865-872.

Pepling ME, Spradling AC. 1998. Female mouse germ cells form synchronously dividing cysts. Development 125: 3323-3328.

Perepelitsa-Belancio V, Deininger P. 2003. RNA truncation by premature polyadenylation attenuates human mobile element activity. Nat Genet 35: 363-366.

Pizarro JG, Cristofari G. 2016. Post-transcriptional control of LINE-1 retrotransposition by cellular host factors in somatic cells. Front Cell Dev Biol 4: 14.

Qiao H, Rao HBDP, Yun Y, Sandhu S, Fong JH, Sapre M, Nguyen M, Tham A, Van BW, Chng TYH, et al. 2018. Impeding DNA break repair enables oocyte quality control. bioRxiv doi: $10.1101 / 277913$.

Richardson SR, Gerdes P, Gerhardt DJ, Sanchez-Luque FJ, Bodea GO, Muñoz-Lopez M, Jesuadian JS, Kempen MHC, Carreira PE, Jeddeloh JA, et al. 2017. Heritable L1 retrotransposition in the mouse primordial germline and early embryo. Genome Res 27: 1395-1405.

Rigby RE, Webb LM, Mackenzie KJ, Li Y, Leitch A, Reijns MA, Lundie RJ, Revuelta A, Davidson DJ, Diebold S, et al. 2014. RNA:DNA hybrids are a novel molecular pattern sensed by TLR9. EMBO J 33: 542-558.

Rinaldi VD, Bolcun-Filas E, Kogo H, Kurahashi H, Schimenti JC. 2017a. The DNA damage checkpoint eliminates mouse oocytes with chromosome synapsis failure. Mol Cell 67: 1026-1036 e1022.

Rinaldi VD, Hsieh K, Munroe R, Bolcun-Filas E, Schimenti JC. 2017b. Pharmacological inhibition of the DNA damage checkpoint prevents radiation-induced oocyte death. Genetics 206: 1823-1828.

Roig I, Dowdle JA, Toth A, de Rooij DG, Jasin M, Keeney S. 2010. Mouse TRIP13/PCH2 is required for recombination and normal higher-order chromosome structure during meiosis. PLoS Genet 6: e1001062.

Royo H, Prosser H, Ruzankina Y, Mahadevaiah SK, Cloutier JM, Baumann M, Fukuda T, Höög C, Toth A, de Rooij DG, et al. 2013. ATR acts stage specifically to regulate multiple aspects of mammalian meiotic silencing. Genes Dev 27: 1484-1494.

Saitou M, Kagiwada S, Kurimoto K. 2012. Epigenetic reprogramming in mouse pre-implantation development and primordial germ cells. Development 139: 15-31.

Schumann GG. 2007. APOBEC3 proteins: Major players in intracellular defence against LINE-1-mediated retrotransposition. Biochem Soc Trans 35: 637-642.

Schuster AT, Sarvepalli K, Murphy EA, Longworth MS. 2013. Condensin II subunit dCAP-D3 restricts retrotransposon mobilization in Drosophila somatic cells. PLoS Genet 9: e1003879.

Schwertz H, Rowley JW, Schumann GG, Thorack U, Campbell RA, Manne BK, Zimmerman GA, Weyrich AS, Rondina MT. 2018. Endogenous LINE-1 (Long Interspersed Nuclear Element-1) reverse transcriptase activity in platelets controls translational events through RNA-DNA hybrids. Arterioscler Thromb Vasc Biol 38: 801-815.

Seisenberger S, Andrews S, Krueger F, Arand J, Walter J, Santos F, Popp C, Thienpont B, Dean W, Reik W. 2012. The dynamics of genome-wide DNA methylation reprogramming in mouse primordial germ cells. Mol Cell 48: 849-862.

Servant G, Streva VA, Derbes RS, Wijetunge MI, Neeland M, White TB, Belancio VP, Roy-Engel AM, Deininger PL. 2017. The nucleotide excision repair pathway limits L1 retrotransposition. Genetics 205: 139-153. 
Sheinberger J, Shav-Tal Y. 2017. mRNPs meet stress granules. FEBS Lett 591: 2534-2542.

Shin YH, Choi Y, Erdin SU, Yatsenko SA, Kloc M, Yang F, Wang PJ, Meistrich ML, Rajkovic A. 2010. Hormad1 mutation disrupts synaptonemal complex formation, recombination, and chromosome segregation in mammalian meiosis. PLoS Genet 6: e1001190.

Shin YH, McGuire MM, Rajkovic A. 2013. Mouse HORMAD1 is a meiosis i checkpoint protein that modulates DNA doublestrand break repair during female meiosis. Biol Reprod 89: 29.

Slotkin RK, Martienssen R. 2007. Transposable elements and the epigenetic regulation of the genome. Nat Rev Genet 8: 272 285.

Soper SF, van der Heijden GW, Hardiman TC, Goodheart M, Martin SL, de Boer P, Bortvin A. 2008. Mouse maelstrom, a component of nuage, is essential for spermatogenesis and transposon repression in meiosis. Dev Cell 15: 285-297.

Stanzione M, Baumann M, Papanikos F, Dereli I, Lange J, Ramlal A, Trankner D, Shibuya H, de Massy B, Watanabe Y, et al. 2016. Meiotic DNA break formation requires the unsynapsed chromosome axis-binding protein IHO1 (CCDC36) in mice. Nat Cell Biol 18: 1208-1220.

Stetson DB, Ko JS, Heidmann T, Medzhitov R. 2008. Trex1 prevents cell-intrinsic initiation of autoimmunity. Cell 134: $587-598$

Subramanian VV, Hochwagen A. 2014. The meiotic checkpoint network: Step-by-step through meiotic prophase. Cold Spring Harb Perspect Biol 6: a016675.

Suh EK, Yang A, Kettenbach A, Bamberger C, Michaelis AH, Zhu Z, Elvin JA, Bronson RT, Crum CP, McKeon F. 2006. p63 protects the female germ line during meiotic arrest. Nature 444: 624-628.

Székvölgyi L, Ohta K, Nicolas A. 2015. Initiation of meiotic homologous recombination: Flexibility, impact of histone modifications, and chromatin remodeling. Cold Spring Harb Perspect Biol 7: a016527.

Tchenio T, Casella JF, Heidmann T. 2000. Members of the SRY family regulate the human LINE retrotransposons. Nucleic Acids Res 28: 411-415.

Tease C, Hartshorne G, Hulten M. 2006. Altered patterns of meiotic recombination in human fetal oocytes with asynapsis and/or synaptonemal complex fragmentation at pachytene. Reprod Biomed Online 13: 88-95.

Tilly JL. 2001. Commuting the death sentence: How oocytes strive to survive. Nat Rev Mol Cell Biol 2: 838-848.

Tilly JL, Sinclair DA. 2013. Germline energetics, aging, and female infertility. Cell Metab 17: 838-850.

Trelogan SA, Martin SL. 1995. Tightly regulated, developmentally specific expression of the first open reading frame from LINE-1 during mouse embryogenesis. Proc Natl Acad Sci 92: $1520-1524$.

Turner JM. 2015. Meiotic silencing in mammals. Annu Rev Genet 49: 395-412.

Vader G, Musacchio A. 2014. HORMA domains at the heart of meiotic chromosome dynamics. Dev Cell 31: 389-391. van der Heijden GW, Bortvin A. 2009. Transient relaxation of transposon silencing at the onset of mammalian meiosis. Epigenetics 4: 76-79.

Vinckenbosch N, Dupanloup I, Kaessmann H. 2006. Evolutionary fate of retroposed gene copies in the human genome. Proc Natl Acad Sci 103: 3220-3225.

Wallace NA, Belancio VP, Deininger PL. 2008. L1 mobile element expression causes multiple types of toxicity. Gene 419: $75-81$.

Wang S, Hassold T, Hunt P, White MA, Zickler D, Kleckner N, Zhang L. 2017. Inefficient crossover maturation underlies elevated aneuploidy in human female meiosis. Cell 168: $977-$ 989 e917.

Ward JR, Vasu K, Deutschman E, Halawani D, Larson PA, Zhang D, Willard B, Fox PL, Moran JV, Longworth MS. 2017. Condensin II and GAIT complexes cooperate to restrict LINE-1 retrotransposition in epithelial cells. PLoS Genet 13: e1007051.

West AMV, Komives EA, Corbett KD. 2018. Conformational dynamics of the Hop1 HORMA domain reveal a common mechanism with the spindle checkpoint protein Mad2. Nucleic Acids Res 46: 279-292.

Wojtasz L, Daniel K, Roig I, Bolcun-Filas E, Xu H, Boonsanay V, Eckmann CR, Cooke HJ, Jasin M, Keeney S, et al. 2009. Mouse HORMAD1 and HORMAD2, two conserved meiotic chromosomal proteins, are depleted from synapsed chromosome axes with the help of TRIP13 AAA-ATPase. PLoS Genet 5: e1000702.

Wojtasz L, Cloutier JM, Baumann M, Daniel K, Varga J, Fu J, Anastassiadis K, Stewart AF, Remenyi A, Turner JM, et al. 2012. Meiotic DNA double-strand breaks and chromosome asynapsis in mice are monitored by distinct HORMAD2-independent and -dependent mechanisms. Genes Dev 26: 958973

Yang N, Kazazian HH Jr. 2006. L1 retrotransposition is suppressed by endogenously encoded small interfering RNAs in human cultured cells. Nat Struct Mol Biol 13: 763-771.

Yang N, Zhang L, Zhang Y, Kazazian HH Jr., 2003. An important role for RUNX3 in human L1 transcription and retrotransposition. Nucleic Acids Res 31: 4929-4940.

Ye Q, Kim DH, Dereli I, Rosenberg SC, Hagemann G, Herzog F, Tóth A, Cleveland DW, Corbett KD. 2017. The AAA+ ATPase TRIP13 remodels HORMA domains through N-terminal engagement and unfolding. EMBO J 36: 2419-2434.

Zhang Z, Harrison PM, Liu Y, Gerstein M. 2003. Millions of years of evolution preserved: A comprehensive catalog of the processed pseudogenes in the human genome. Genome Res 13: 2541-2558.

Zhang A, Dong B, Doucet AJ, Moldovan JB, Moran JV, Silverman RH. 2014. RNase L restricts the mobility of engineered retrotransposons in cultured human cells. Nucleic Acids Res 42: $3803-3820$.

Zickler D, Kleckner N. 1999. Meiotic chromosomes: Integrating structure and function. Annu Rev Genet 33: 603-754.

Zickler D, Kleckner N. 2015. Recombination, pairing, and synapsis of homologs during meiosis. Cold Spring Harb Perspect Biol 7: a016626. 


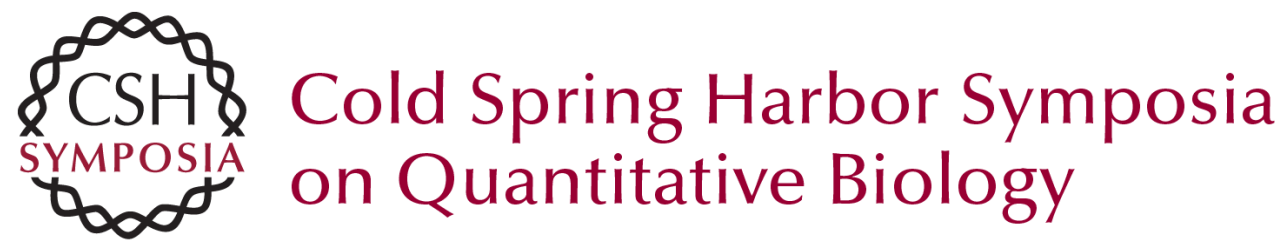

\section{Oocyte Quality Control: Causes, Mechanisms, and Consequences}

Neil Hunter

Cold Spring Harb Symp Quant Biol 2017 82: 235-247 originally published online May 9, 2018 Access the most recent version at doi:10.1101/sqb.2017.82.035394

References This article cites 158 articles, 41 of which can be accessed free at: http://symposium.cshlp.org/content/82/235.full.html\#ref-list-1

Creative This article is distributed under the terms of the

Commons http://creativecommons.org/licenses/by-nc/4.0/, which permits reuse and License redistribution, except for commercial purposes, provided that the original author and source are credited.

Email Alerting Receive free email alerts when new articles cite this article - sign up in Service the box at the top right corner of the article or click here. 